\title{
A STUDY ON KNOWLEDGE, ATTITUDE, BEHAVIOUR, AND PRACTICE OF BIOMEDICAL WASTE MANAGEMENT AMONG STAFF OF A TERTIARY TEACHING HOSPITAL IN TAMILNADU, INDIA.
}

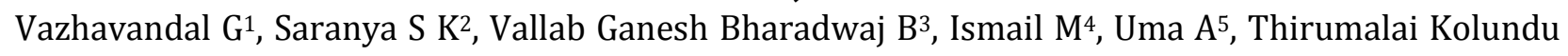
Subramanian $\mathrm{P}^{6}$

\section{HOW TO CITE THIS ARTICLE:}

Vazhavandal G, Saranya SK, Vallab Ganesh Bharadwaj B, Ismail M, Uma A, Thirumalai Kolundu Subramanian P "A study on knowledge, attitude, behaviour, and practice of biomedical waste management among staff of a tertiary teaching hospital in Tamilnadu, India". Journal of Evolution of Medical and Dental Sciences 2013; Vol2, Issue 29, July 22; Page: 5472-5483.

ABSTRACT: Hospitals generate a large quantity of waste that should be properly collected, segregated, stored, transported, and disposed by health care professionals. Efforts are being taken to sensitize, motivate, and practice proper waste management and disposal through training, Continuing Medical Education (CME), and departmental meetings. OBJECTIVES: This study was carried out to evaluate existing knowledge, attitude, behaviour and practice (KABP) of biomedical waste management (BMWM) among Doctors, Nurses and other auxiliary staff of a tertiary teaching hospital. METHODS: A pretested questionnaire containing 25 questions were given to the study category of Staff, tabulated and analyzed by using SPSS 17. RESULT: This study showed that 76\% of the staff was aware of the quantity of waste generated daily. Knowledge among doctors was high when compared to nurses and auxiliary staff. CME programmes were less effective than learning through theory and seminars. Though $61.5 \%$ of the participants already attended the refresher training programme, $82 \%$ showed interest to undergo training which implies that those who have already undergone training wanted to get refresher training again to strengthen their knowledge. Only $86 \%$ of participants wanted to label the bins with biohazard symbol and $79.8 \%$ of staff informed of practicing BMWM .Regarding weighing of biomedical waste (BMW) only 55\% of staff were aware of weighing of BMW, maintaining registers and auditing. However $93.5 \%$ agree that BMWM is a teamwork and $24.5 \%$ informed that BMWM is an extra burden on the work. DISCUSSION: The knowledge, attitude, and practice among auxiliary staff are to be strengthened by sustained training programmes, CME and departmental review meetings.

KEYWORDS: Continuing Medical Education, Biomedical Waste Management, Biomedical Waste.

INTRODUCTION: The waste generated at hospitals, dispensaries and health care centre are grouped into bio medical waste (BMW). The hospital waste consists of general waste and biomedical waste which includes infectious waste, pathological waste, sharps, chemical waste, pharmaceutical waste, waste with high heavy metal contents, nano-medicines/material waste, radioactive waste, genotoxic waste, and pressurized waste ${ }^{2}$. 3. According to new 2011 amendments in BMWM rules, high heavy metal contents, nano-medicines/material waste, radioactive waste, genotoxic waste, and pressurized waste are not included in BMW and are dealt by separate rules ${ }^{13}$. Mostly BMW generated in health care centre vary from 10 to $25 \%$ and the remaining $75 \%$ to $90 \%$ of the waste produced by the health care providers is general or non risk waste ${ }^{1}$. It is further subdivided into infectious or non-infectious waste. It has been estimated that about one to two kg of waste are generated per bed per day which accounts for 330,000 tons of waste/year in India ${ }^{3}$.As more and 


\section{ORIGINAL ARTICLE}

more hospitals and clinics are developing in India, it is expected that BMW generated is also likely to increase.

The Government of India framed rules through the ministry of Environment and Forest [MOEF] by a notification in July 1998 to provide uniform guidelines, code of practices for the whole nation to adhere. The Rules define the biomedical waste components and instructed all health care establishments to chalk out a programme to implement it, assess the situation, treatment and disposal and allotted responsibilities to each level. This institute adheres to the rules and regulation of Govt. of India rules notified in S.0.1035 [E] for the segregation, storage, transport, treatment and disposal of Bio Medical Waste ${ }^{13}$.

Hence, the health care workers (HCW) have to be aware of BMWM. The knowledge, attitude, behaviour and practice (KABP) of biomedical waste management vary from country to country and even within the country among health care workers. However, these depend upon the existence and enforcement of laws in handling proper waste management practices ${ }^{2}$. Even though basic legislation exists in India, the biomedical waste management is not found to be at the expected level because of varied reasons. It is also very important to elicit the KABP of HCW of respective hospitals in order to understand their levels and introduce remedial measures. Keeping the above in mind the present study was undertaken.

MATERIAL AND METHODS: The study was conducted in a teaching hospital at Trichirapalli, Tamilnadu. A pretested anonymous questionnaire was given to the participants during June and July 2012 [Annexure]. Those Participants who have undergone any training programme on BMWM within last one year were excluded from this study. On the day of study a meeting was called for doctors and then questionnaire was given to the doctors. They were explained about the importance of the study. Among the 150 doctors 112 responded (74.6\%). The remaining 38 underwent training. So they were excluded. Second week, a meeting was organised for nurses \& auxiliary staff who were of day duty. Among the participants 50 nurses, 50 auxiliary staff including lab technicians, and housekeeping staff attended the meeting and they were asked to answer the questions. Of them 42 nurses (84\%) and 46 auxiliary staff $(92 \%)$ responded to the survey. The anonymity of the participants was maintained throughout the study. The questionnaire contained 22 closed questions and 3 open questions and was related to knowledge, attitude, and practice. Information obtained through the questionnaire was analysed using the statistical software SPSS v. 17.0.

OBSERVATION AND RESULTS: The quantity of biomedical waste generated by every ward and departments daily varied. Most of the participants (76\%) were aware of waste generated in their ward. About $24 \%$ of participants did not know the daily quantity of waste generated in their ward and department (Figure-1). 


\section{ORIGINAL ARTICLE}

Table-1: Knowledge of Biomedical Waste Management

\begin{tabular}{|l|l|l|l|l|l|l|}
\hline \multirow{2}{*}{} & \multicolumn{2}{|c|}{ Doctors (n=112) } & \multicolumn{2}{c|}{ Nurses (n=42) } & \multicolumn{2}{c|}{ Others (n=46) } \\
\cline { 2 - 7 } & $\begin{array}{c}\text { Present/ } \\
\text { Yes }\end{array}$ & $\begin{array}{c}\text { Absent/ } \\
\text { No }\end{array}$ & $\begin{array}{c}\text { Present/ } \\
\text { Yes }\end{array}$ & $\begin{array}{c}\text { Absent/ } \\
\text { No }\end{array}$ & $\begin{array}{c}\text { Present/ } \\
\text { Yes }\end{array}$ & $\begin{array}{c}\text { Absent/ } \\
\text { No }\end{array}$ \\
\hline Knowledge of Law & $59(52.6 \%)$ & $53(47.4 \%)$ & $22(52.4 \%)$ & $20(47.6 \%)$ & $12(26.1 \%)$ & $34(73.9 \%)$ \\
\hline Learnt through theory & $67(59.8 \%)$ & $45(40.2 \%)$ & $18(42.9 \%)$ & $24(57.1 \%)$ & $17(36.9 \%)$ & $29(63.1 \%)$ \\
\hline Learnt through CME & $37(33.1 \%)$ & $75(66.9 \%)$ & $17(40.5 \%)$ & $25(59.5 \%)$ & $2(4.3 \%)$ & $44(95.7 \%)$ \\
\hline $\begin{array}{l}\text { Learnt through } \\
\text { seminar }\end{array}$ & $32(28.5 \%)$ & $80(71.5 \%)$ & $17(40.5 \%)$ & $25(59.5 \%)$ & $20(43.5 \%)$ & $26(56.5 \%)$ \\
\hline $\begin{array}{l}\text { Attended training } \\
\text { programmes on } \\
\text { BMWM }\end{array}$ & $41(36.6 \%)$ & $71(63.4 \%)$ & $24(57.2 \%)$ & $18(42.8 \%)$ & $12(26.1 \%)$ & $34(73.9 \%)$ \\
\hline $\begin{array}{l}\text { A hospital providing } \\
\text { annual education on } \\
\text { BMWM }\end{array}$ & $49(43.7 \%)$ & $63(56.3 \%)$ & $29(69.1 \%)$ & $13(30.9 \%)$ & $31(67.4 \%)$ & $15(32.6 \%)$ \\
\hline $\begin{array}{l}\text { Categorizing Wastes- } \\
\text { Necessary }\end{array}$ & $108(96.4 \%)$ & $4(3.6 \%)$ & $30(71.4 \%)$ & $12(28.6 \%)$ & $39(84.8 \%)$ & $7(15.2 \%)$ \\
\hline $\begin{array}{l}\text { Color coding disposal- } \\
\text { Necessary }\end{array}$ & $112(100 \%)$ & - & $40(95.2 \%)$ & $2(4.8 \%)$ & $38(82.6 \%)$ & $8(17.4 \%)$ \\
\hline $\begin{array}{l}\text { Labeling of BMW with } \\
\text { Biohazard symbol }\end{array}$ & $99(88.3 \%)$ & $13(11.7 \%)$ & $36(85.7 \%)$ & $6(14.3 \%)$ & $36(78.3 \%)$ & $10(21.7 \%)$ \\
\hline
\end{tabular}

Abbreviations: BMW - Biomedical Waste (Percentage in Parenthesis)

BMWM - Biomedical Waste Management

Practice of Biomedical Waste Management at the hospital was observed to be good and 91\% of the participants were aware of the hospital Biomedical Waste management plan. Majority of the participants $(80 \%)$ said that they were taught to dispose waste carefully and properly. Their work related to segregation, decontamination, transport, and storage was monitored by medical professionals of concerned department and 74.5\% participants agreed to it. About $74 \%$ agreed that department heads were discussing biomedical waste management in their departmental meetings (Figure-2).

Regular audit was carried out in the hospital to check the practice of biomedical waste management. Some departments maintain registers for the biomedical waste disposal and 56\% recorded the weight of the wastes generated daily (Figure-3). The hospital wastes were segregated and disposed properly in an authorized hospital waste collection centre.

Attitude of participants towards Biomedical Waste Management was good. About $71 \%$ participants consider that it was an issue to maintain proper waste management, $93.5 \%$ participants considered it as a team work, and $40 \%$ and $24.5 \%$ of participants agreed that it increased financial burden and work burden respectively (Figure-4).

Government of India framed biomedical waste rules in 1998, and 1st amendments in March 2000 and recent amendment in May 2011. However, in this study 52.6\% Doctors, 52.4\% nurses, and $26.1 \%$ auxiliary staff expressed the knowledge of the law. The doctors have stated that they gained the knowledge of BMW through theory (59.8\%) rather than CME (33.1\%) and training (28.5\%). 


\section{ORIGINAL ARTICLE}

However, the nurses gained BMW knowledge through theory (18\%), CME (17\%), and training (17\%) respectively. Nevertheless the knowledge among the auxiliary staff (Lab technicians, and housekeeping staff) was minimal (28.23\%).

This hospital conducted training on BMW. But only 36.6\% doctors, $24 \%$ nurses and $12 \%$ auxiliary staff have attended the training. The annual education programme on BMW has expected impact on nurses (69.1\%) and auxiliary staff (67.1\%) but not on doctors (43.7\%). On categorizing BMW, all the categories of staff expressed the importance of proper categorizing the wastes $(96.4 \%$. $71.4 \%$, and $84.8 \%$ ).All the doctors (100\%) accepted color coding is necessary and $95.2 \%$ of the nurses also gave importance for color coding bags for segregation at the disposal stage. At the same time the doctors, nurses and auxiliary staff want to be label the color coded bins in the biohazard symbol. [Table-1]

Discussion:

The study was conducted using a pretested questionnaire to assess the knowledge, attitude, and practice of Biomedical Waste Management among the health care workers. From the result obtained, it was observed that overall awareness and practice on Biomedical Waste Management is satisfactory with few deficiencies. Doctors were more interested to participate in the research on biomedical waste than other staff. It was also observed that the doctors had better knowledge than nurses and laboratory technicians. This study concurs the study of Kedar et al [2007] at Kathmandu valley ${ }^{7}$. The housekeeping staff was found to be unaware of the ill effects of the Biomedical Waste and this led to a decrease in the overall percentage of the knowledge of Biomedical Waste Management. This study concurs the findings of the Shalini Sharma et al [2007] in threegovernment hospital in Agra ${ }^{8}$. They need training, since they are at high risk of being infected or injured by the Biomedical Waste, which contains high quantities of organic and pathogenic wastes. Many participants were aware of the color coding system and labeling of the biomedical waste with Biohazard symbol. Those who are ignorant about the color coding system and Biohazard symbol are likely to mix the hazardous infectious waste with non-hazardous general wastes, and making them infectious and also increase the cost of management of those wastes as well as amplify environmental pollution.

Practice is also found to be satisfactory because of the compulsive acts of the hospital administration and interest of the health care workers who were sensitized on importance of Biomedical Waste Management. Regular departmental meetings had improved the knowledge of the doctors, nurses and laboratory technicians over the practice of Biomedical Waste Management when compared to that of housekeeping staff, which showed the same situation prevailed at Gujarat in a study conducted by Pandit et al [2004] $]^{9}$. The practice of Biomedical Waste Management as per the Biomedical Waste (Management and Handling) rules 1998 is done to a certain extent in a few departments.

Only less numbers of participants had awareness about the treatment modalities of different categories of waste. This knowledge has to be spread to all the health care workers of the hospital.

Participants' attitude was better than their practice. They agreed that Biomedical Waste Management has to be maintained properly as teamwork. This will decrease the spread of infections by the waste within the hospital and in the environment.

These results are in accordance with the results of the study done by Waseem et al, [2007] wherein the doctors were well aware of Biomedical Waste hazards, and poor knowledge of its 


\section{ORIGINAL ARTICLE}

adverse consequences among others. Moderate level of knowledge and awareness were attributed to the training programmes attended by the participants and the discussion in departmental meetings as well as regular auditing and training on Biomedical Waste Management. The adverse effects of Biomedical Waste should be properly taught. Certain lacunae in the knowledge and practice of Biomedical Waste Management are because of few health care workers in the hospital who are not willing to attend programmes on Biomedical Waste Management.

CONCLUSION: Efforts have to be initiated to prevent nosocomial infections and environmental pollution in the hospital settings by planning, executing a proper biomedical waste management programme with trained supervisors. In addition, steps have to be made to reduce the burden of treatment of all wastes and to reduce cost of management. To have effective biomedical waste management all Government and private health care clinics are to be compulsorily registered under pollution control board for proper monitoring and adherence to the rules and regulations of Government of India act and guidelines issued in July 1998 and amended in May 2011 scrupulously .Since we are following Tamil Nadu Pollution control board for the state which is under the control of GOI act, we have not evaluated knowledge regarding amendments made in 2011.

To have effective BMW management the existing law to be properly enforced and all local bodies such as town panchayats, municipalities and corporation should have scientific disposal of BMW collected from health care institutions and this disposal activity by the local bodies are to be monitored by pollution control board. Suitable modifications are to be done in the undergraduate medical curriculum in medical and paramedical courses to give more emphasize on proper collection, segregation, disinfection and disposal of BMW. Periodical training programmes, CMEs, and reorientation programmes on BMW management are to be conducted in all health care facilities for all health care personals. Knowledge on solar disinfection of biomedical waste management is also to be imparted to reduce the cost of disinfection. ${ }^{10}$ Deep burial of anatomical wastes is suggested when incineration facility is not available. ${ }^{11}$

A national level apex body to be constituted with regulations to conduct periodical and surprise check of all health care facilities for the proper segregation, disinfection, storage , transport and proper disposal.

ACKNOWLEDGEMENT: We would like to acknowledge STS-2012 program of Indian Council of Medical Research (ICMR) for funding our study. The authors wholeheartedly acknowledge the cooperation and co-ordination extended by various clinical departments to conduct this study. Further the authors thank medical and paramedical staff for their help to complete this study successfully.

STRENGTH AND LIMITATIONS OF THE STUDY: The strength of the study is that all the categories of health care workers are included in the study, which helped to assess their knowledge among those categories of people separately. The response rate is $83.5 \%$. Limitation of the study is that it is done in a single institution and it did not cover workers of the operation theatre.

\section{REFERENCES:}




\section{ORIGINAL ARTICLE}

1. Basu M, Das P, Pal R. Assessment of future physicians on biomedical waste management in a tertiary care hospital of West Bengal. Journal of Natural Science, Biology and Medicine, 2012; 3(1):38-42

2. Vyas. D.S, Dave U.B, Prakash. H.B. The Safe Disposal of bio-Medical Waste (Case study of a rural medical hospital). National conference on Recent Trends in Engineering \&Technology, May 2011; 13-14.

3. Waseem Q, Hassan. G, Wani. N.A, Baba. A, Kadri. S.M. Awareness of Biomedical Waste Management amongst Staff of the Government S M H S Hospital, Srinagar, A tertiary Level Hospital in Kashmir Valley. hospital's today, JK-Practitioner 2007;14(1): 60-61

4. Archisman M, Manoj G.K, Sidddharudha S, Mishra C.P, Mohapatra S.C, Biomedical waste Management practices of Doctors: An online snapshot. National Journal of Community Medicine, 2012; 3 (2): 227-231.

5. Mathew S.S, Benjamin. A.I, Sengupta P. Assessment of biomedical waste management practices in tertiary hospital in Luthiana. Health line 2011; 2(2): 28-30.

6. Banzal M, Mishra A, Gautam P, Chagulani R, Srivastava D, Gour. NS,. National journal of Community Medicine, 2011; 2 [3]: 452-456.

7. Rijal K, Despande A, Critical Evaluation of Biomedical management Practices in Kathmandu valley. Proceedings of International conference on Sustainable Solid waste Management, Sep 2007; 142-147.

8. Sharma S, Chauhan. S.V.S. Assessment of biomedical waste management in three apex government hospitals of Agra. Journal of Environmental Biology, 2008; 29(2): 159-162.

9. Pandit NB, Mehta HK, Kartha GP, Choudhary SK. Management of biomedical waste: awareness and practices in a district of Gujarat, India J Public Health 2005;49: 245-7.

10. Chitnis V, Chitnis S, Patil S, Chitnis D. Solar disinfection of infectious biomedical waste: a new approach for developing countries. Lancet 2003; 362: 1285-6.

11. Mastorakis N E, Bulucea C A, Oprea T A, Bulucea C A, Dondon P. Environmental and health risks associated with biomedical waste management; Development, Energy, Environment, Economics. 2010; 288-294.

12. Ministry of Environment and Forests (MOEF) Rules, Government of India - Notification July 1998.New S.0. 630 (E)

13. Ministry of Environment and Forests (MOEF) Rules, Government of India - Notification May 2011 S.O. 1035(E) 


\section{ORIGINAL ARTICLE}

Figure-1: Quality of Biomedical Waste generated daily.

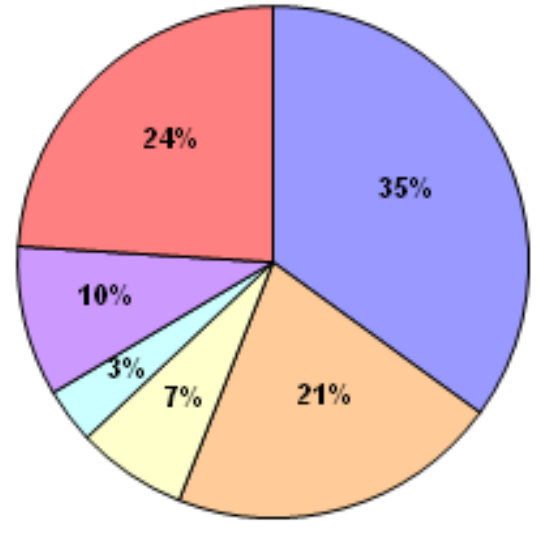

प1 - $5 \mathrm{~kg}$

$\square 5-10 \mathrm{~kg}$

$\square 10-15 \mathrm{~kg}$

$\square 15-20 \mathrm{~kg}$

$\square 20+\mathbf{k g}$

口Not known

Figure-2: Practice of Biomedical Waste Management in the Hospital

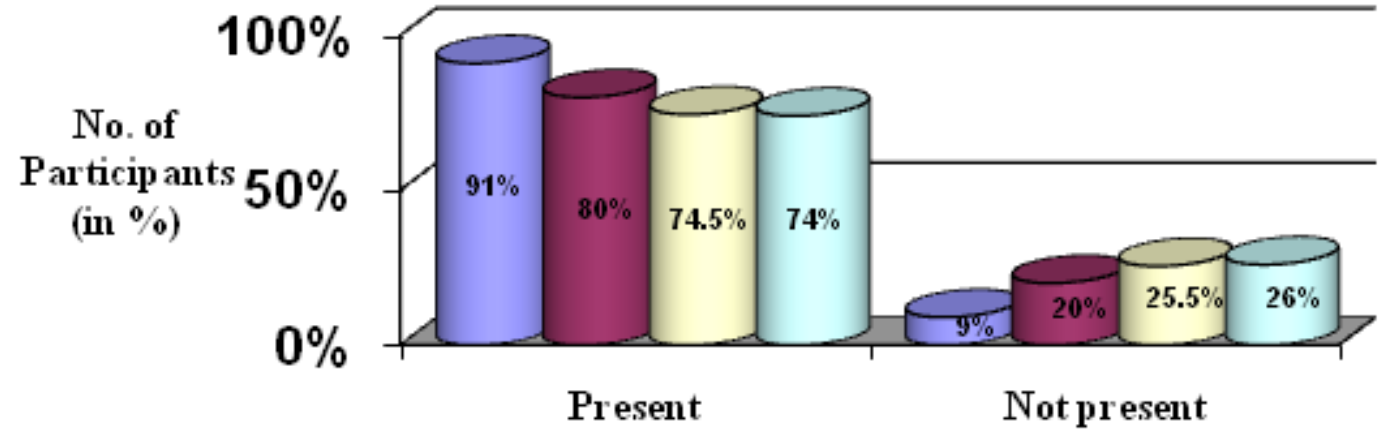

口BMW management Plan

anstruction for proper disposal of Biomedical Waste Management

口Monitoring of activities

$\square$ Discussion of importance of Biomedical Waste Management in Departmental Meeting 


\section{ORIGINAL ARTICLE}

Figure-3: Auditing, Register Maintenance and Weighing of Biomedical Waste
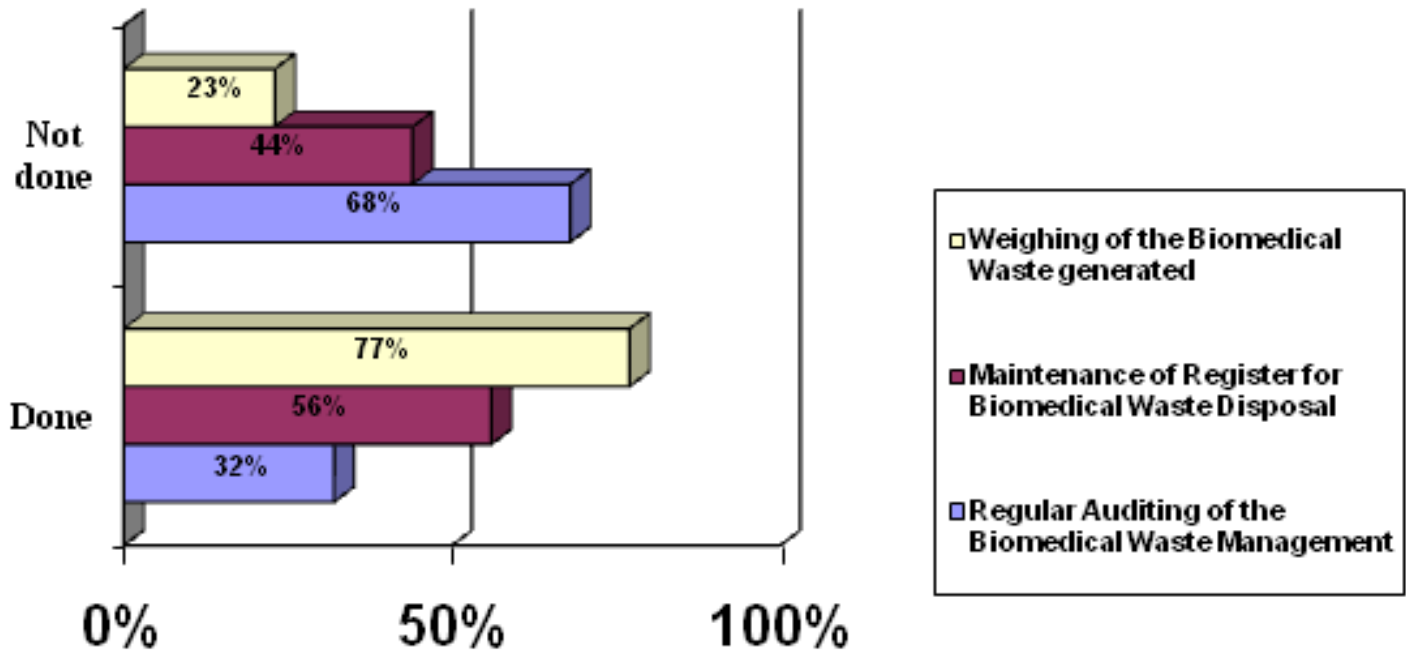

No. of Participants

(in \%)

Figure-4: Attitude on Biomedical Waste Management

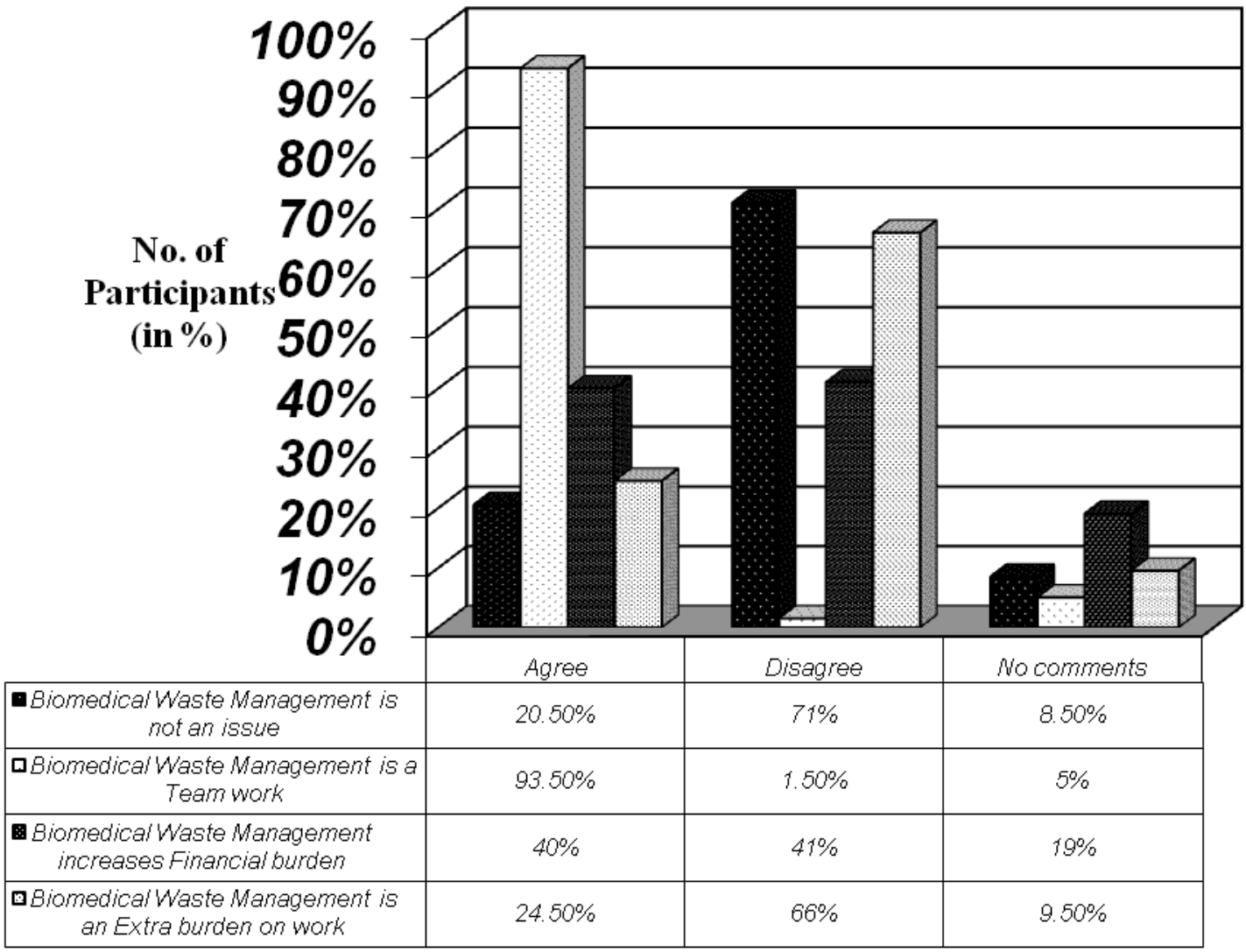




\section{ORIGINAL ARTICLE}

\section{ANNEXURE}

1. Person interviewed:
a. Doctor
d. Nurse
b. Resident
e. Others

c. CRRI

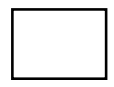

Department in which you are working/attached at present:
2. a) Age.
[ ]
b) Gender: Male / Female

3. What is the quantity of waste generated every day in your department?
a. $1-5 \mathrm{~kg}$
d. $15-20 \mathrm{~kg}$
b. $5-10 \mathrm{~kg}$ more than $20 \mathrm{~kg}$
c. $10-15 \mathrm{~kg}$ don't know

\section{Waste Management Policy:}

1. Are you aware of any law applicable to the hospital waste management?

Yes

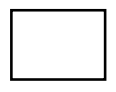

No

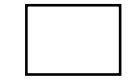

If yes, please list the legislative Act

2. Does your institution have a biomedical waste management plan?

Yes

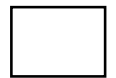

No

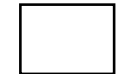

3. Have you been instructed to take care of the biomedical waste disposal in your ward?

Yes

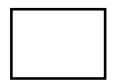

No

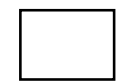

4. Are your biomedical waste disposal activities monitored by your immediate higher authority?

Yes<smiles>C1CCC1</smiles>

No

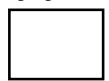

5. How have you learnt on biomedical waste management?
a) Theory lectures
b) CME
c) Seminar

Yes
Yes
Yes

No
No
No

6. Is the importance of the biomedical waste management discussed in department meeting?

Yes
No

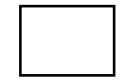

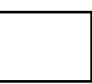




\section{ORIGINAL ARTICLE}

\section{Waste Management Practices:}

7. Tick the facilities available for biomedical waste treatment and disposal in your hospital
a. Segregation
b. Storage
c. Burial
d. Deep Burial
e. Burning
f. Auto clave
g. Incineration

8. Should biomedical waste be segregated into different categories?

Yes

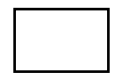

No

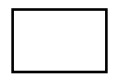

If YES, who does the segregation?
a. Doctor

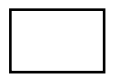
b. Nurse

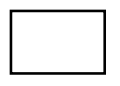
C. Nursing assistant
d. Axillary staff

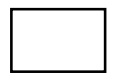
e. Do not know

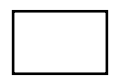

9. Do you think that biomedical waste has to be disposed in colour coded bags?

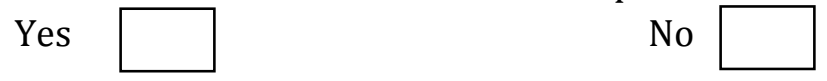

If yes, match the following:

\begin{tabular}{|l|l|l|l|l|l|}
\hline & \multicolumn{1}{|c|}{ Waste } & Type of bag & Ans & Treatment & Ans \\
\hline 1 & $\begin{array}{l}\text { Amputated limb, placenta, dead } \\
\text { fetus }\end{array}$ & Red plastic bag & $\begin{array}{l}\text { Incinerator/ } \\
\text { Deep burial }\end{array}$ & Disposal landfill \\
\hline 3 & $\begin{array}{l}\text { Blood soaked gauze, bandages, } \\
\text { plasters } \\
\text { ampoules, glass vials, suturing } \\
\text { needles }\end{array}$ & Black plastic bag & Yellow plastic bag \\
\hline 4 & $\begin{array}{l}\text { Expired drugs, chemical wastes, } \\
\text { cytotoxic drugs }\end{array}$ & $\begin{array}{l}\text { Blue puncture } \\
\text { proof container }\end{array}$ & $\begin{array}{l}\text { Autoclave/ } \\
\text { Microwave }\end{array}$ & $\begin{array}{l}\text { Autoclave/ } \\
\text { Microwave }\end{array}$ & \\
\hline
\end{tabular}

10. Is the infectious waste labeled with the Bio-Hazard Symbol?

Yes

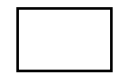

No $\square$

11. Has your institution does a biomedical waste audit in regularly? 
Yes

No

12. Where do you dispose biomedical waste in your hospital premises?

a. Dumping in corporation /municipal/ panchayat bin

b. Any authorized hospital waste collection

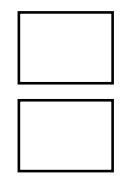

c. Any other specify

13. Do you maintain a register for biomedical waste disposal in your ward?

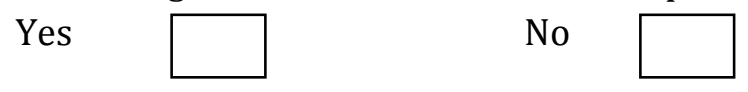

14. Do you weigh the biomedical waste generated in your ward?

Yes



No


15. Safe management of health

care waste is not an issue at all.

16. Biomedical waste management is team work
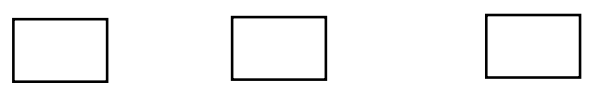

Hospital increases financial burden on

management

18. Safe management of Health Care

waste is an extra burden on work
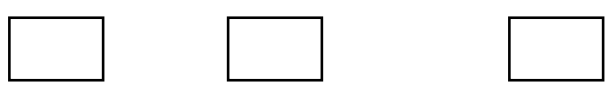

19. Have you undergone any training programme in Hospital Waste Management?

Yes

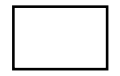

No

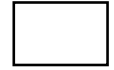

20. Does your hospital provide annual education on biomedical waste management for employee?

Yes

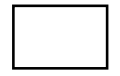

No

21. Would you like to attend a programme on Hospital Waste Management?

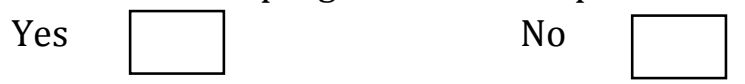

22. Mention your area of interest in biomedical waste management
a. Source
b. Segregation

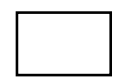
c. Storage

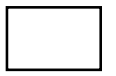
d. Disposal
e. Laws related to biomedical waste management

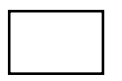
f. None

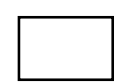

23. Were/Are you involved in any research activity related to biomedical waste management?

Yes

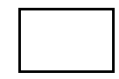

No

Journal of Evolution of Medical and Dental Sciences/ Volume 2/ Issue 29/ July 22, 2013

Page 5482 
If yes, please mention the type of research.

24. Are you interested in research related to biomedical waste management?

Yes

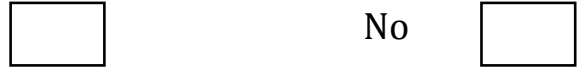

25. Your comment on biomedical waste management

\section{AUTHORS:}

1. Vazhavandal G.

2. Saranya S K.

3. Vallab Ganesh Bharadwaj B.

4. Ismail M.

5. Uma A.

6. Thirumalai Kolundu Subramanian P.

\section{PARTICULARS OF CONTRIBUTORS:}

1. Assistant Professor, Department of Microbiology, Chennai Medical College Hospital and Research Centre (SRM Group), Irungalur, Tiruchirapalli, Tamilnadu, India.

2. Pre-Final M.B.B.S Student, Department of Microbiology, Chennai Medical College Hospital and Research Centre (SRM Group), Irungalur, Tiruchirapalli, Tamilnadu, India 621 105.

3. Assistant Professor, Department of Microbiology, Chennai Medical College Hospital and Research Centre, (SRM Group), Irungalur, Tiruchirapalli, Tamilnadu, India.

4. Research Co-ordinator, Health Science Research, Department of Microbiology, Chennai Medical College Hospital and Research Centre (SRM Group), Irungalur, Tiruchirapalli, Tamilnadu, India.
5. Professor and Head, Department of Microbiology, Chennai Medical College Hospital and Research Centre, (SRM Group), Irungalur, Tiruchirapalli, Tamilnadu, India.

6. Professor and Head, Department of Medicine, Chennai Medical College Hospital and Research Centre, (SRM Group), Irungalur, Tiruchirapalli, Tamilnadu, India.

\section{NAME ADRRESS EMAIL ID OF THE} CORRESPONDING AUTHOR:

Dr. G. Vazhavandal,

Dept. of Microbiology,

D 4 Staff Quarters,

Chennai Medical College Hospital and Research

Centre,

(SRM Group), Irungalur, Tiruchirapalli,

Tamilnadu, India 621105

Email- hemarathinam2006@gmail.com

Date of Submission: 18/07/2013.

Date of Peer Review: 18/07/2013.

Date of Acceptance: 22/07/2013.

Date of Publishing: 22/07/2013 